\title{
sciendo
}

\section{THE EFFECT OF UNSATURATED FATTY ACID CONCENTRATION ON THE AROMA PROFILE OF GOAT'S MILK}

\author{
Dorota Cais-Sokolińska ${ }^{1}$, Jacek Wójtowski ${ }^{\star}$, Jan Pikul ${ }^{1}$, Romualda Danków ${ }^{1}$, Małgorzata Majcher ${ }^{3}$, \\ Joanna Teichert ${ }^{1}$, Emilia Bagnicka ${ }^{4}$ \\ ${ }^{1}$ Department of Dairy Product Quality, Faculty of Food Science and Nutrition, \\ Poznań University of Life Sciences, 60-624 Poznań, Poland \\ ${ }^{2}$ Department of Animal Breeding and Product Quality Assessment, Faculty of Veterinary Medicine \\ and Animal Science, Poznań University of Life Sciences, 62-002 Suchy Las, Poland \\ ${ }^{3}$ Department of Food Chemistry and Instrumental Analysis, Faculty of Food Science and Nutrition, \\ Poznań University of Life Sciences, 60-624 Poznań, Poland \\ ${ }^{4}$ Institute of Genetics and Animal Breeding of the Polish Academy of Sciences, 05-552 Magdalenka, \\ Poland \\ •Corresponding author: jacwojto@gmail.com
}

\begin{abstract}
In this study, varying concentrations of polyunsaturated fatty acids in goat's milk were obtained by supplementing goat feed rations with maize dried distillers grains with solubles (DDGS). In comparison to the control group, the milk of goats that received DDGS contained about $25 \%$ more polyunsaturated fatty acids, $30 \%$ more conjugated linoleic acid (CLA), and had more favorable values of the atherogenic and thrombogenic indices. The diverse composition of fatty acids present in the goat's milk correlated with the olfactory perception of the milk and its volatile compound profile. The level of unsaturated fatty acids significantly affected the odors detected in the processed goat's milk. The volatile compound profile of the milk was mostly differentiated by the concentrations of aldehydes (hexanal and furfural) and furanones (furaneol), which exceeded their odor threshold values. The total concentration of identified aldehydes was highest in pasteurized milk samples from the goats of the experimental group, as a result of heating. Furfural was found in pasteurized samples of both the control and experimental milk at concentrations exceeding its odor threshold (3 $\left.\mathrm{mg} \cdot \mathrm{kg}^{-1}\right)$. Feeding goats with DDGS did not change the animal, cooked, dairy fat, lack of freshness, light-oxidized, or overall dairy flavors of the raw milk. After pasteurization, milk from goats fed with DDGS retained its characteristic animal odor and gained a very intense cooked flavor.
\end{abstract}

Key words: goat's milk, volatile compound profile, unsaturated fatty acids, odor threshold values

The volatile compounds found in goat's milk depend on its hygienic status and the composition of the feed fed to the livestock (Pereira et al., 2010; Steinshamn et al., 2014). The type of feed given to livestock also plays an important role in modi- 
fying the bioactive compounds found in the milk (Coppa et al., 2011). Appropriate selection of nutritional components can modify the milk's fatty acid profile, thus lowering the amount of short-chain and medium-chain saturated fatty acids and increasing unsaturated acids (Chilliard et al., 2007).

Dried distillers grains with solubles (DDGS) are by-products of the distillation process employed in the beverage and ethanol fuel industries. In the USA, maize is the predominant feedstock used to produce ethanol, but other grains and carbohydrate-containing feedstocks can also be used (Leonardi et al., 2005). Several studies have found that cows fed a diet rich in DDGS which has a high unsaturated fatty acid content, typically with over 60 percent linoleic acid showed modest increases in the concentrations of unsaturated fatty acids in their milk (Leonardi et al., 2005; Anderson et al., 2006). The same authors also reported modest increases in cis-9, trans-11 conjugated linoleic acid and its precursor, vaccenic acid (trans-11 C18:1), which have been associated with improved health in humans (Anderson et al., 2006). Gurung et al. (2009) described the effects of DDGS on feed intake, growth, gain efficiency, selected blood metabolites, and carcass quality of goats. Very few studies have been conducted on the application of DDGS in the nutrition of dairy goats (Dennis et al., 2012). In one of the first papers on the subject, Cais-Sokolińska et al. (2015) confirmed the advantageous effects of DDGS for example, on the concentration of polyunsaturated fatty acids in goat's milk.

The aroma of milk can alter significantly when an animal feedstuff enriched with supplements high in unsaturated fatty acids is used (Bendall, 2001). Raising the unsaturated fatty acid (UFA) concentration of milk fat can also increase the concentration of UFA oxidation and degradation products (Wójtowski et al., 2003; Islam et al., 2015). In this regard, $\beta$-oxidation at double bonds may lead to the formation of straight-chain aldehydes and ketones, which may be converted to the corresponding alcohols under reducing conditions (Nursten, 1997). Increased UFA concentrations in milk may thus adversely affect the sensory attributes of milk primarily the aroma (Smith et al., 2016).

In this study, we investigated how changes in the level of unsaturated fatty acids in goat's milk affect the sensory profile and concentrations of volatile compounds in the milk. Varied concentrations of unsaturated fatty acids have been obtained by supplementing goat feed rations with maize dried distillers grains with solubles (DDGS).

\section{Material and methods}

\section{Experimental design}

The milk in this study was collected from Polish White Improved goats. Animal care was provided in accordance with EU Directive 2010/63/EU. The animals were kept in an indoor housing system on a goat farm in western Poland. The goats were randomly allocated from a herd of one hundred female goats into one of two groups: the control group (16 head) and the experimental group receiving DDGS (16 head). The animals had an average body weight of $56 \mathrm{~kg}( \pm 4 \mathrm{~kg})$ and were aged between 
3 and 4 years (during their second and third lactation). All the goats were at the same lactation stage, at $105 \pm 7$ days in milk at the beginning of trial. The goats in this study were fed either a basal diet (the control) or the basal diet plus $12 \mathrm{~g} \cdot 100 \mathrm{~g}^{-1}$ of DDGS dry matter (DM) maize concentrate (the experimental group). The composition of the feed rations employed has been described in detail in the study of CaisSokolińska et al. (2015). After a thirty-day period of adaptation to the experimental diet, individual milk samples were collected every other day for the next twelve days at morning and evening milkings $(2 \times 250 \mathrm{~mL})$. The goats were milked by machine.

Daily samples of milk from individual animals were prepared by mixing milk from the morning and evening milkings (1:1). Subsequently, the daily milk samples were combined in a separate bulk tank for each group. In this way, 24 samples of bulk tank milk (12 for the control and 12 for the experimental group) were obtained for chemical analysis. These bulk milk samples were processed in a dairy plant. All chemical analyses were carried out on two duplicates.

\section{Basic composition and FA analysis}

The basic chemical composition of the cooled raw milk was analyzed immediately after milking. The fatty acid (FA) profile was determined in raw milk freezestored for 4-7 days at a temperature of $-20^{\circ} \mathrm{C}$. The fatty acid profiles of the control and experimental milks ( $\mathrm{g} \cdot 100 \mathrm{~g}^{-1}$ of total FA) were analyzed using the protocol described by Cais-Sokolińska et al. (2015).

The nutritional quality indices of the lipids were determined using the fatty acids, estimating the unsaturated fatty acids (UFA) by summing the polyunsaturated (PUFA) and monounsaturated (MUFA) fatty acids, and the desirable fatty acids (DFA) by summing the unsaturated fatty acids and the stearic acid:

\section{$\mathrm{DFA}=(\mathrm{UFA}+\mathrm{C} 18: 0)$}

The atherogenic (AI) and thrombogenic indices (TI) were calculated using the equations of Ulbricht and Southgate (1991).

AI $($ atherogenic index $)=[\mathrm{C} 12: 0+(4 \times \mathrm{C} 14: 0)+\mathrm{C} 16: 0] /[\mathrm{MUFA}+(n-6 \mathrm{PUFA})+(n-3$ PUFA)]

$\mathrm{TI}($ thrombogenic index $)=(\mathrm{C} 14: 0+\mathrm{C} 16: 0+\mathrm{C} 18: 0) /(0.5 \times \mathrm{MUFA})+(0.5 \times n-6$ PUFA $+3 \times n-3$ PUFA $)+(n-3$ PUFA $/ n-6$ PUFA $)$

The concentrations of fat, protein, and lactose were determined using a FoodScan Lab apparatus (FOSS, Hillerød, Denmark). The hygienic status of the milk was determined with a somatic cell count (SCC) using an IBCm instrument (Bentley, MN, USA).

The milk underwent sensory evaluation and volatile compound analysis approximately four hours after the morning milking. The milk was stored at $4 \pm 0.5^{\circ} \mathrm{C}$ and then pasteurized by heating to $85^{\circ} \mathrm{C}$ for $5 \mathrm{~min}$ in a plate pasteurizer. The raw and pasteurized milk samples were stored and cooled in glass ampoules $(40 \mathrm{~mL})$ equipped with nuts with silicone and Teflon gaskets, and in this way isolated from external factors.

\section{Assessment of volatile compound profiles}

Volatile compound profiles were assessed using headspace solid phase microextraction (HS-SMPE) coupled with gas chromatography and time-of-flight mass 
spectrometry (GC/TOFMS, Serra et al., 2009). The $7 \mathrm{~g}$ samples were placed in dearomatized $20 \mathrm{~cm}^{3}$ dishes, spiked with $1 \mu \mathrm{g}$ of phenol $\mathrm{d}_{6}$ internal standard, and sealed with a cap containing a Teflon and silicone membrane. The volatile compounds were extracted using a CAR/DVB/PDMS fiber with a $50 \mu \mathrm{m}$ stationary phase (Bellefonte, USA). Extraction was performed at $50^{\circ} \mathrm{C}$ for $40 \mathrm{~min}$. After extraction, the fiber was transferred to the injection chamber of the gas chromatograph and compounds were desorbed for $5 \mathrm{~min}$ at $260^{\circ} \mathrm{C}$ in splitless mode for $1 \mathrm{~min}$. To separate and identify the volatiles, a GC $\times$ GC-TOFMS system (Pegasus IV, LECO, St. Joseph, IL, USA) was used, running in single-dimensional chromatography mode with a modulation time of 0 seconds. The GC was equipped with RTX-5 $(10 \mathrm{~m} \times 0.18 \mathrm{~mm} \times 0.2 \mu \mathrm{m})$ and BPX-50 $(1.3 \mathrm{~m} \times 0.1 \mathrm{~mm} \times 0.1 \mu \mathrm{m})$ columns. Helium with a flow rate of $0.8 \mathrm{~cm}^{3} \cdot \mathrm{min}^{-1}$ was used as a carrier gas. In the case of the RTX-5 column, an initial temperature of $50^{\circ} \mathrm{C}$ was held for $1 \mathrm{~min}$, before increasing at $12^{\circ} \mathrm{C} \cdot \mathrm{min}^{-1}$ to the final temperature of $240^{\circ} \mathrm{C}$; for the BPX-50 column, the secondary oven was kept $30^{\circ} \mathrm{C}$ hotter than the primary oven. The mass spectra were collected at a speed of 10 scans $\cdot \mathrm{s}^{-1}$ with an ionizing energy of $70 \mathrm{eV}$ and a scan range of $\mathrm{m} / \mathrm{z} 33-350$. The transfer line was maintained at $280^{\circ} \mathrm{C}$. The compounds were identified by comparing the mass spectra obtained with the NIST 98 mass spectral libraries (Güzel-Seydim et al., 2000) and with reference standards. The mixture of n-alkanes $\left(\mathrm{C}_{6}-\mathrm{C}_{20}\right)$ dissolved in hexane to determine the retention index was supplied by Supelco (Bellefonte, PA, USA). The calculations were performed using Chroma TOF software (version 3.32).

\section{Gustatory and olfactory evaluation of the milk samples}

Sensory evaluation was carried out using the profiling method described by Cais-Sokolińska et al. (2015). The panel was made up of ten trained people who had been prepared for the evaluation. The panelists exhibited no known illnesses at the time of examination and possessed audited olfactory and gustatory functions. In preceding weekly training sessions, ten assessors (four males and six females; age range: 21-56) were recruited and trained for at least half a year in orthonasal and retronasal recognition of selected odors at different concentrations. An intensity scale from 1 to 10 points was used, where 1 indicated a barely detectable odor and 10 a very intense odor (Karagul-Yuceer et al., 2001). The samples were prepared according to Spitzer and Buettner (2010). Each panelist evaluated each sample in triplicate.

\section{Statistical analysis}

The effect of feed supplementation on the fatty acid profile of milk was assessed statistically using PROC MIXED from SAS (2006), with the goat diet effect as class variable. Least square means were compared using Scheffe's test. Differences were taken to be significant at $\mathrm{P}<0.05$. Sensory evaluation was carried out to determine the location of the test samples in the perception space. The results were evaluated using principal component analysis (PCA, Stampanoni, 1994). The odor and flavor descriptors of Drake (2004) were used. 
Table 1. Fatty acids profiles of control and experimental goat milk ( $\mathrm{g} \cdot \mathrm{kg}^{-1}$ fatty acid methyl esters,

FAME, mean \pm SD)

\begin{tabular}{|c|c|c|}
\hline Fatty acids (\% FAME) & Control group & Experimental group \\
\hline C18:0 & $8.12 \mathrm{a} \pm 0.91$ & $9.90 \mathrm{~b} \pm 0.89$ \\
\hline C18:1c9 & $23.72 \pm 2.11$ & $26.32 \pm 2.38$ \\
\hline C18:1c11-15 & $1.51 \pm 0.13$ & $1.66 \pm 0.12$ \\
\hline C18:1t9-10 & $1.71 \pm 0.21$ & $2.28 \pm 0.32$ \\
\hline C18:1t11 & $0.29 \mathrm{a} \pm 0.05$ & $0.85 \mathrm{~b} \pm 0.11$ \\
\hline $\mathrm{C} 18: 2 \mathrm{c} 9 \mathrm{c} 12$ & $2.42 \mathrm{a} \pm 0.28$ & $2.95 \mathrm{~b} \pm 0.34$ \\
\hline $\mathrm{C} 18: 3 \mathrm{c} 9 \mathrm{c} 12 \mathrm{c} 15$ & $0.31 \mathrm{~b} \pm 0.04$ & $0.17 \mathrm{a} \pm 0.03$ \\
\hline $\mathrm{SFA}^{1)}$ & $65.15 \mathrm{~b} \pm 2.51$ & $60.28 \mathrm{a} \pm 2.34$ \\
\hline UFA $^{2)}$ & $34.85 \mathrm{a} \pm 3.01$ & $39.72 b \pm 3.19$ \\
\hline $\mathrm{DFA}^{3)}$ & $42.97 \pm 3.98$ & $49.62 \pm 4.45$ \\
\hline MUFA $^{4)}$ & $30.80 \mathrm{a} \pm 2.78$ & $34.59 \mathrm{~b} \pm 2.92$ \\
\hline MUFA $c i s^{5)}$ & $25.24 \mathrm{a} \pm 3.08$ & $27.98 \mathrm{~b} \pm 3.33$ \\
\hline MUFA $\operatorname{trans}^{(6)}$ & $3.46 \mathrm{a} \pm 0.33$ & $4.49 \mathrm{~b} \pm 0.35$ \\
\hline PUFA $^{7)}$ & $4.05 \mathrm{a} \pm 0.36$ & $5.13 \mathrm{~b} \pm 0.42$ \\
\hline $\mathrm{CLA}^{8)}$ & $1.08 \mathrm{a} \pm 0.17$ & $1.41 \mathrm{~b} \pm 0.19$ \\
\hline$n-3^{9)}$ & $0.42 \mathrm{~b} \pm 0.08$ & $0.27 \mathrm{a} \pm 0.09$ \\
\hline$n-6^{10)}$ & $2.46 \mathrm{a} \pm 0.27$ & $2.97 \mathrm{~b} \pm 0.21$ \\
\hline$n-6 / n-3$ & $5.88 \pm 0.15$ & $10.94 \pm 0.19$ \\
\hline $\mathrm{AI}^{11)}$ & $2.29 \mathrm{a} \pm 0.21$ & $1.79 \mathrm{~b} \pm 0.16$ \\
\hline $\mathrm{TI}^{12)}$ & $2.73 \pm 0.23$ & $2.38 \pm 0.19$ \\
\hline
\end{tabular}

1) SFA - saturated fatty acids (C4:0, C6:0, C8:0, C10:0, C12:0, C13 iso, C14:0, C15:0, C15 iso, C16:0, $\mathrm{C} 17: 0, \mathrm{C} 17$ iso, C18:0, C19:0, C20:0, C22:0, C24:0).

2) UFA - unsaturated fatty acids (C14:1, C16:1, MUFA cis, MUFA trans, C20:1, C22:1, C24:1 C18:2 c9 c12, $\mathrm{C} 18: 2 \mathrm{c} 9 \mathrm{c} 15, \mathrm{C} 18: 2 \mathrm{c} 9 \mathrm{t} 11, \mathrm{C} 18: 2 \mathrm{t} 10 \mathrm{c} 12, \mathrm{C} 18: 3 \mathrm{c} 9 \mathrm{c} 12 \mathrm{c} 15, \mathrm{C} 20: 3, \mathrm{C} 20: 4, \mathrm{C} 22: 5, \mathrm{C} 22: 6)$.

$\left.{ }^{3}\right)$ DFA - desirable fatty acids (UFA + C18:0).

${ }^{4)}$ MUFA - monounsaturated fatty acids (C14:1, C16:1, MUFA cis, MUFA trans, C20:1, C22:1, C24:1).

${ }^{5)}$ MUFA cis (C18:1c9, C18:1c11, C18:1c12, C18:1c13, C18:1c14, C18:1c15).

${ }^{6}$ MUFA trans (C18:1t9, C18:1t10, C18:1t11, C18:1t12, C18:1t15).

7) PUFA - polyunsaturated fatty acids (C18:2 c9 c12, C18:2 c9 c15, C18:2 c9 t11, C18:2t10 c12, C18:3 c9 c12 c15, C20:3, C20:4, C22:5, C22:6).

${ }^{8)} \mathrm{CLA}$ - conjugated linoleic acid (C18:2c9t11,C18:2t10c12).

${ }^{9)} n-3$ PUFA (C18:3 c9 $\left.\mathrm{c} 12 \mathrm{c} 15, \mathrm{C} 20: 3, \mathrm{C} 22: 5, \mathrm{C} 22: 6\right)$.

10) $n$-6 PUFA (C18:2 c9 c12, C20:2, C20:3, C20:4).

${ }^{11)} \mathrm{AI}-$ Atherogenic index [C12:0+(4 x C14:0 $\left.)+\mathrm{C} 16: 0\right] /[\mathrm{MUFA}+(n-6 \mathrm{PUFA})+(n-3 \mathrm{PUFA})]$.

${ }^{12)} \mathrm{TI}-$ Thrombogenic index $(\mathrm{C} 14: 0+\mathrm{C} 16: 0+\mathrm{C} 18: 0) /(0.5 \times$ MUFA $)+(0.5 \times n-6$ PUFA $+3 \times n-3$ PUFA $)+(n-3$ PUFA $/ n-6$ PUFA).

$\mathrm{a}, \mathrm{b}-$ mean values within each row with different letters are significantly different $(\alpha=0.05)$.

\section{Results}

\section{Effects of DDGS on the fatty acid profile of goat's milk}

The addition of DDGS to the feed had no significant effect on the basic chemical composition of the milk ( $\mathrm{P}>0.05)$. The concentrations of the primary components of the milk from goats fed the DDGS supplement, in comparison with those in the 
control group, were: fat: $3.43 \%( \pm 0.31 \%)$ and $3.37 \%( \pm 0.29 \%)$; protein: $3.36 \%( \pm$ $0.21 \%)$ and $3.41 \%( \pm 0.22 \%)$; and lactose: $4.60 \%( \pm 0.12 \%)$ and $4.56 \%( \pm 0.11 \%)$. Somatic cell counts in milk from the experimental and control groups were similar $\left(282 \times 10^{3}\right.$ vs. $298 \times 10^{3}$ cells $\left.\mathrm{mL}^{-1}\right)$. These results indicate that the milk was obtained from goats with healthy mammary glands (Wójtowski et al., 2002; Danków et al., 2003).

The use of DDGS as a dietary supplement led to a reduction in the levels of saturated fatty acids (SFA) in the milk of animals from the experimental group, as compared to the milk of goats in the control group $(\mathrm{P}<0.05$, Table 1$)$. The milk obtained from animals in the experimental group had significantly higher levels of monounsaturated fatty acids than that obtained from animals in the control group. The concentrations of both cis and trans MUFA were higher in the DDGS-supplemented group than in the control $(\mathrm{P}<0.05)$. In addition, the concentration of polyunsaturated fatty acids was significantly higher $(\mathrm{P}<0.05)$, by nearly $25 \%$, in the milk from the experimental group. The positive impact of feeding goats the DDGS supplement was demonstrated by it having a significantly higher $(\sim 30 \%$; $<<0.05)$ CLA content (C18:2c9t11 and C18:2t10c12) than the control-group milk. It was also observed that milk from goats in the experimental group contained fewer $n-3$ acids and more $n-6$ acids $(\mathrm{P}<0.05)$ than did milk from the control group.

The introduction of DDGS into the feed had significant effects on the values of the atherogenic index (AI), with better values observed for the goats in the experimental group $(\mathrm{P}<0.05$, Table 1$)$.

\section{Sensory evaluation of goat's milk aroma}

DDGS supplementation was reflected in the sensory evaluation profiles of the odor components and in the evaluation of the tested raw milk samples and pasteurized samples, depending on the unsaturated fatty acid contents (Table 2). The cooked odor was more intense following pasteurization. This odor was more detectable to the panelists in those goat's milk samples that contained more unsaturated fatty acids $\left(\mathrm{x}_{\mathrm{r}}=4.2\right.$ points $)$ than in the milk from the control group $\left(\mathrm{x}_{\mathrm{r}}=2.9\right.$ points $)$. In contrast, a lightly oxidized odor was found in milk obtained from both groups, with pasteurization not influencing its intensity.

Animal odor was the weakest differentiating odor among the milks: its intensity was independent of other evaluation descriptors. The intensity of this odor was not affected by pasteurization or by unsaturated fatty acid content. The level of unsaturated fatty acids significantly affected the odor of the processed raw goat's milk. Initially, the odor of the goat's milk that contained more unsaturated fatty acids was $76 \%$ more detectable. Its level in milk obtained from goats in both groups was similar in samples that underwent pasteurization. In the pasteurized goat's milk samples, a grainy odor was similarly detectable, although this was twice as detectable in the unpasteurized milk from goats in the experimental group $(\mathrm{P}<0.05)$. In the evaluation of grainy odor, raw goat's milk with higher levels of unsaturated fatty acids was twice as aromatic as the pasteurized milk.

The dairy-sweet odor correlated significantly with the overall dairy odor $\left(r^{2}=0.97 ; y=0.57 x+5.49\right)$ and was approximately $20 \%$ more intense in the raw 
control milk than in the milk with a higher content of unsaturated fatty acids. Pasteurization intensified this odor 1.4-fold in the control milk and 2-fold in the milk with higher UFA levels. The overall dairy odor of the raw milk was independent of the unsaturated fatty acid levels. Pasteurization enhanced the intensity of this odor by an average of $12 \%$ in the control milk and $16 \%$ in the milk from goats fed the DDGS supplement. The intensification of the cooked and dairy-sweet odors, as well as the weakening of the dairy fat and grainy odors, may have led to the increased perception of the overall dairy odor of the pasteurized milk with the higher levels of unsaturated fatty acids.

Table 2. Sensory evaluation descriptors of goat milk odour and flavour depending on the unsaturated fatty acid content and heating, scale $1-10, n=12, \pm$ SD

\begin{tabular}{l|c|c|c|c}
\hline \multicolumn{1}{c}{ Descriptors } & RC & RE & PC & PE \\
\hline Animal & $3.8 \pm 0.1 \mathrm{a}$ & $3.6 \pm 0.3 \mathrm{a}$ & $3.7 \pm 0.1 \mathrm{a}$ & $3.7 \pm 0.2 \mathrm{a}$ \\
Cooked & $1.3 \pm 0.2 \mathrm{a}$ & $1.3 \pm 0.4 \mathrm{a}$ & $2.9 \pm 0.1 \mathrm{~b}$ & $4.2 \pm 0.3 \mathrm{c}$ \\
Dairy fat & $2.8 \pm 0.1 \mathrm{~b}$ & $2.7 \pm 0.7 \mathrm{~b}$ & $1.4 \pm 0.1 \mathrm{a}$ & $1.5 \pm 0.3 \mathrm{a}$ \\
Dairy sweet & $3.4 \pm 0.3 \mathrm{~b}$ & $2.8 \pm 0.2 \mathrm{a}$ & $4.9 \pm 0.6 \mathrm{c}$ & $4.6 \pm 0.3 \mathrm{c}$ \\
Grainy & $1.2 \pm 0.1 \mathrm{a}$ & $2.5 \pm 0.2 \mathrm{~b}$ & $1.1 \pm 0.4 \mathrm{a}$ & $1.4 \pm 0.1 \mathrm{a}$ \\
Lack of freshness & $1.7 \pm 0.1 \mathrm{a}$ & $1.3 \pm 0.2 \mathrm{a}$ & $1.1 \pm 0.5 \mathrm{a}$ & $1.0 \pm 0.4 \mathrm{a}$ \\
Light-oxidized & $4.2 \pm 0.2 \mathrm{a}$ & $4.0 \pm 0.3 \mathrm{a}$ & $3.7 \pm 0.1 \mathrm{a}$ & $3.9 \pm 0.6 \mathrm{a}$ \\
Overall dairy & $7.4 \pm 0.3 \mathrm{a}$ & $7.0 \pm 0.4 \mathrm{a}$ & $8.3 \pm 0.2 \mathrm{~b}$ & $8.1 \pm 0.1 \mathrm{~b}$ \\
Processed & $2.1 \pm 0.4 \mathrm{a}$ & $3.7 \pm 0.2 \mathrm{~b}$ & $3.3 \pm 0.2 \mathrm{~b}$ & $3.5 \pm 0.2 \mathrm{~b}$ \\
\hline
\end{tabular}

$\mathrm{RC}$ - raw milk obtained from goats from the control group.

$\mathrm{RE}$ - raw milk obtained from goats from the experimental group with a higher content of unsaturated fatty acids.

$\mathrm{PC}$ - pasteurized milk $\left(85^{\circ} \mathrm{C} / 5 \mathrm{~min}\right)$ obtained from goats from the control group.

$\mathrm{PE}$ - pasteurized milk $\left(85^{\circ} \mathrm{C} / 5 \mathrm{~min}\right)$ obtained from goats from the experimental group with a higher content of unsaturated fatty acids.

$\mathrm{SD}$ - standard deviation.

$\mathrm{a}, \mathrm{b}, \mathrm{c}-$ small letters in rows represent the statistic differences relevant for $\alpha=0.05$.

Odors such as lack of freshness, light oxidization, and dairy fat were convergent with each other, which is shown by their common location in the first quadrant of the principal component plane projection. The odor described as a lack of freshness in raw milk was significantly lower in the milk with higher UFA levels and in the pasteurized milk. Following pasteurization, an approximately $50 \%$ reduction in dairy fat odor was reported, independently of UFA levels.

Evaluation of all the descriptors in the examined milk samples and their mixtures also facilitated the identification of similarities between the groups (Figure 1). Similar odor profiles were observed in the pasteurized milk, regardless of unsaturated fatty acid content. The odor of both pasteurized milk samples was significantly different from the odor profile of the raw milk. In the case of raw milk, the levels of unsaturated fatty acids significantly affected the specific odor profile of the milk samples. 


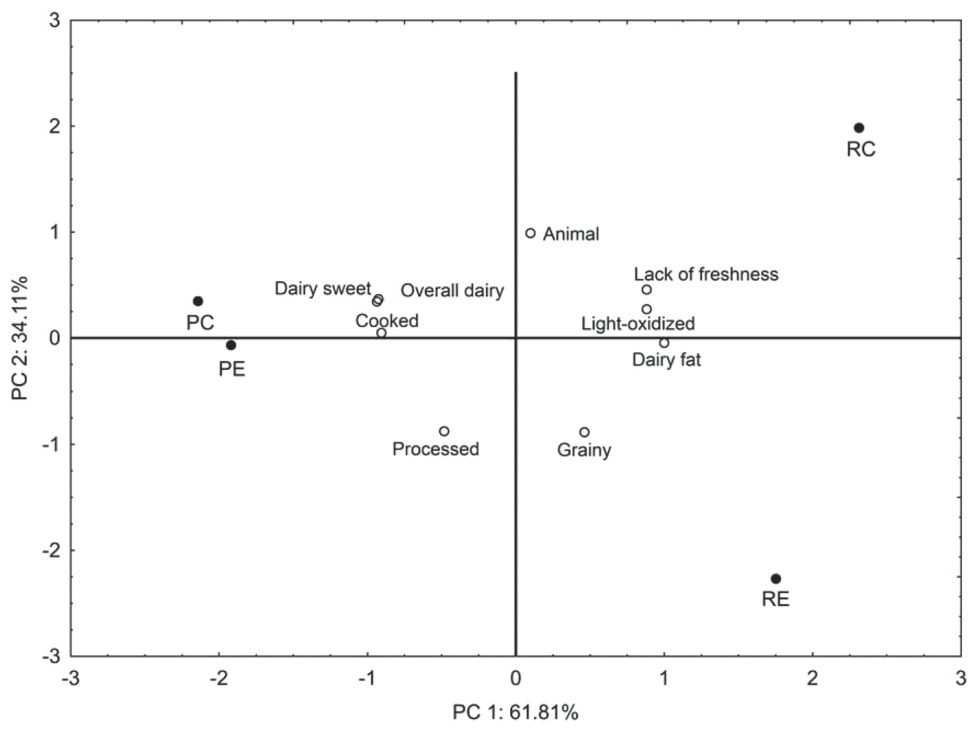

Figure 1. Standardized analysis biplot of the principal components profile results of the goat milk odors with varying contents of unsaturated fatty acid

$\mathrm{RC}$ - raw milk obtained from goats from the control group.

$\mathrm{RE}$ - raw milk obtained from goats from the experimental group with a higher content of unsaturated fatty acids.

$\mathrm{PC}$ - pasteurized milk $\left(85^{\circ} \mathrm{C} / 5 \mathrm{~min}\right)$ obtained from goats from the control group.

$\mathrm{PE}$ - pasteurized milk $\left(85^{\circ} \mathrm{C} / 5 \mathrm{~min}\right)$ obtained from goats from the experimental group with a higher content of unsaturated fatty acids.

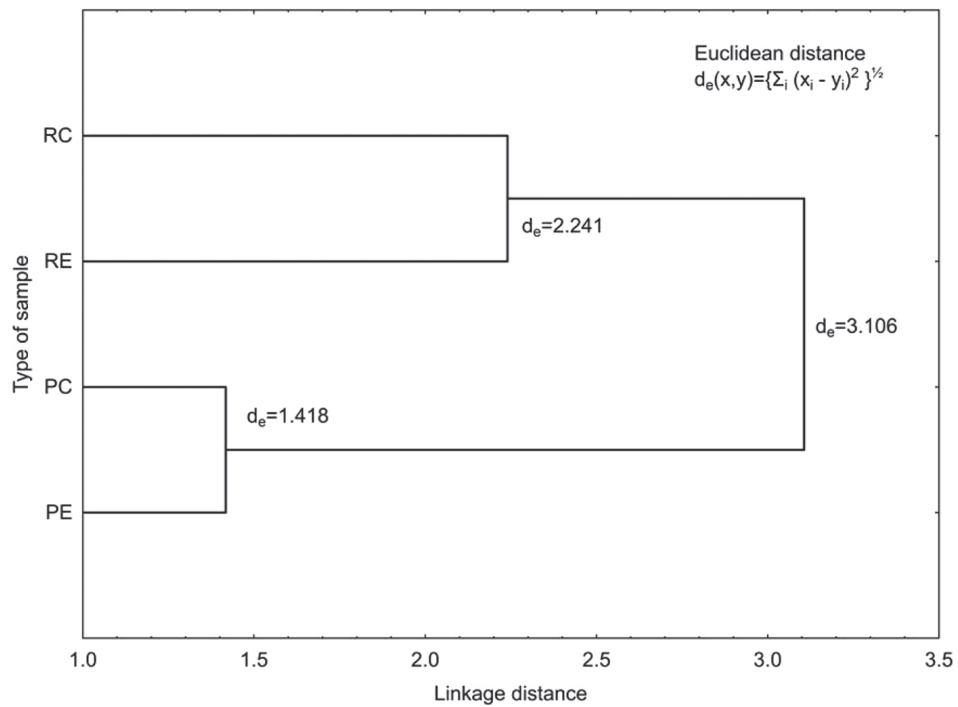

Figure 2. The dendrogram of the concentration analysis of the goat milk sample connection grade, $\mathrm{n}=12$, marked as in Figure 1 
Feeding goats with DDGS did not alter the animal, cooked, dairy fat, lack of freshness, light-oxidized, or overall dairy flavors of the raw milk. On the other hand, the sense of sweet dairy was reduced and the sensation of the grainy and processed odors and flavors was increased in the raw milk. Pasteurized milk from the goats in the experimental group with higher levels of unsaturated fatty acids than the pasteurized milk from the control goats also possessed a more intense cooked odor and flavor. This sensation of cookedness related to the combination of brown flavor notes and aromatics associated with heated milk. In the case of the remaining eight, there were no differences between the pasteurized and control milk in terms of odor and flavoring.

Convergence of the odor profiles of the milk samples was evaluated on the basis of the Euclidean distances of their mutual connections (Figure 2). The connection distance was shortest for the pasteurized goat's milk of both feeding groups, which indicates their high sensory similarity $\left(\mathrm{d}_{\mathrm{e}}=1.418 ; \mathrm{r}=0.943 ; \mathrm{P}=0.311\right)$.

\section{Volatile compound profiles and their effects on the odor of goat's milk}

The results of profiling the volatile compounds that affect the milks' odors are presented in Table 3. The volatile characteristics of both control (RC) and experimental (RE) raw milk samples were due to a very small number of aromatic compounds: only a few carboxylic acids, methyl ketones, alcohols, and terpenes were present.

It is well known that flavor of the raw milk of any mammal is characteristic and yet subtle, being delicate and involving few compounds. Moio et al. (1993) used gas chromatography olfactometry to identify seven potent odorants in raw cow, sheep, goat, and water buffalo milks. There was, however, a difference between the control (RC) and experimental (RE) groups, in that milk supplemented with DDGS showed a higher concentration of volatiles, such as free fatty acids and methyl ketones.

This variation in volatile composition correlated with the sensory evaluation, in which the panelists clearly distinguished both samples, describing the experimental raw milk (RE) as grainier and less animal-like, and the control raw milk samples (RC) as characterized by light oxidation and dairy fat. The number of volatiles in raw milk samples is so small that it is difficult to directly associate odor descriptors with specific volatile compounds.

The results of the volatile profile analysis, presented in Table 3, show that the pasteurization process has a much greater effect than supplementing the animal diet with DDGS. The pasteurized samples contain much higher levels than raw milk of all volatile groups other than terpenes. In general, the effect of pasteurization is more noticeable in the experimental milk (PE), since the total volatile content increased 15-fold, rather than 9-fold as in the control sample (PC). The increase was noticeable for acetic, hexanoic, octanoic, decanoic, or tetradecanoic acids. However, the change may be noticeable in sensory evaluation only in the case of hexanoic acid, since its concentration in pasteurized samples is higher than its odor threshold (OT, $0.89 \mathrm{mg} \cdot \mathrm{kg}^{-1}$ ); this may be associated with a processed odor note. On the other hand, the concentrations of butanoic and dodecanoic acids were lower in pasteurized milk samples than in the experimental raw milk samples. As the OT of butanoic acid has been reported to be $1 \mathrm{mg} \cdot \mathrm{kg}^{-1}$ of water level, it can be assumed that it could affect the overall aroma and distinguish this sample from others only in the experimental 
samples. The presence of butyric acid in milk is a result of auto-oxidation transformations that occur between components of milk under the influence of temperature, UV radiation, and other external factors.

Table 3. Concentration $\left(\mathrm{mg} \cdot \mathrm{kg}^{-1}\right)$ of volatile compounds in the headspace of goat milk with different share of unsaturated fatty acids analysed by SPME/GC/TOF-MS method, $n=12$

\begin{tabular}{|c|c|c|c|c|c|c|}
\hline $\begin{array}{c}\text { Compound } \\
\left(\mathrm{mg} \cdot \mathrm{kg}^{-1}\right)\end{array}$ & $\mathrm{RI}^{* *}$ & \begin{tabular}{|l|} 
Unique \\
Mass $^{* * * *}$ \\
\end{tabular} & $\mathrm{RC}$ & $\mathrm{RE}$ & $\mathrm{PC}$ & $\mathrm{PE}$ \\
\hline 1 & 2 & 3 & 4 & 5 & 6 & 7 \\
\hline \multicolumn{7}{|l|}{ Acids } \\
\hline Acetic acid & 640 & 60 & 0.112 & $0.207 \mathrm{a}$ & $2.811 \mathrm{~b}$ & $3.089 \mathrm{c}$ \\
\hline Butanoic acid & 784 & 60 & nd & $1.309 \mathrm{~b}$ & $0.321 \mathrm{a}$ & $0.442 \mathrm{a}$ \\
\hline Hexanoic acid & 952 & 60 & nd & $0.011 \mathrm{a}$ & $1.235 \mathrm{~b}$ & $1.745 \mathrm{c}$ \\
\hline Octanoic acid & 1142 & 60 & nd & nd & $1.055 \mathrm{a}$ & $1.123 \mathrm{a}$ \\
\hline Decanoic acid & 1336 & 60 & nd & $0.074 \mathrm{a}$ & $1.647 \mathrm{~b}$ & $1.611 \mathrm{~b}$ \\
\hline Dodecanoic acid & 1529 & 60 & nd & $1.512 \mathrm{~b}$ & $0.844 \mathrm{a}$ & $0.800 \mathrm{a}$ \\
\hline Tetradecanoic acid & 1751 & 60 & nd & nd & $0.741 \mathrm{a}$ & $0.603 \mathrm{a}$ \\
\hline sum of acids & & & $0.112 \mathrm{a}$ & $3.113 \mathrm{~b}$ & $8.654 \mathrm{c}$ & $9.413 \mathrm{c}$ \\
\hline \multicolumn{7}{|l|}{ Sulfur compounds } \\
\hline Methanethiol & 473 & 48 & nd & nd & $0.501 \mathrm{a}$ & $0.819 \mathrm{~b}$ \\
\hline Dimethyl sulfide & 514 & 62 & nd & nd & $0.892 \mathrm{~b}$ & $0.595 \mathrm{a}$ \\
\hline Disulfide, dimethyl & 738 & 94 & nd & nd & $0.877 \mathrm{~b}$ & $0.561 \mathrm{a}$ \\
\hline Dimethyl sulfone & 912 & 94 & $0.022 \mathrm{a}$ & nd & $0.637 \mathrm{~b}$ & $1.793 \mathrm{c}$ \\
\hline sum of sulfur compounds & & & $0.022 \mathrm{a}$ & nd & $2.907 \mathrm{~b}$ & $3.840 \mathrm{c}$ \\
\hline \multicolumn{7}{|l|}{ Ketones } \\
\hline 2-Pentanone & 668 & 86 & nd & $0.013 \mathrm{a}$ & $0.045 \mathrm{a}$ & $0.247 \mathrm{~b}$ \\
\hline 2-Heptanone & 875 & 71 & nd & $0.422 \mathrm{~b}$ & $0.032 \mathrm{a}$ & $0.088 \mathrm{a}$ \\
\hline 2-Nonanone & 1077 & 58 & nd & nd & $0.011 \mathrm{a}$ & $0.074 \mathrm{a}$ \\
\hline 2-Undecanone & 1276 & 58 & nd & nd & $0.045 \mathrm{a}$ & $0.021 \mathrm{a}$ \\
\hline 2-Tridecanone & 1487 & 58 & nd & $0.116 \mathrm{~b}$ & $0.005 \mathrm{a}$ & $0.065 \mathrm{~b}$ \\
\hline sum of ketones & & & nd & $0.551 \mathrm{~b}$ & $0.138 \mathrm{a}$ & $0.495 \mathrm{~b}$ \\
\hline \multicolumn{7}{|l|}{ Alcohols } \\
\hline Ethyl alcohol & 459 & 46 & 0.089 & nd & nd & nd \\
\hline 1-Penten-3-ol & 690 & 83 & 0.005 & nd & nd & nd \\
\hline 2-Furanmethanol & 844 & 70 & nd & nd & nd & 0.021 \\
\hline sum of alcohols & & & $0.094 \mathrm{a}$ & nd & nd & $0.021 \mathrm{a}$ \\
\hline \multicolumn{7}{|l|}{ Aldehydes } \\
\hline Hexanal & 785 & 56 & nd & nd & $0.002 \mathrm{a}$ & $0.088 \mathrm{~b}$ \\
\hline Furfural & 825 & 95 & nd & nd & $4.123 \mathrm{a}$ & $9.985 \mathrm{~b}$ \\
\hline 2,5-Furandicarboxaldehyde & 1076 & 123 & nd & nd & nd & 1.509 \\
\hline sum of aldehydes & & & nd & nd & $4.131 \mathrm{a}$ & $11.582 \mathrm{~b}$ \\
\hline \multicolumn{7}{|l|}{ Furans and furanones } \\
\hline 2,5-dimethyl-furan & 693 & 95 & nd & nd & $0.069 \mathrm{a}$ & $0.712 \mathrm{~b}$ \\
\hline $2(5 \mathrm{H})$-furanone & 913 & 84 & nd & nd & $1.214 \mathrm{a}$ & $3.114 \mathrm{~b}$ \\
\hline
\end{tabular}


Table 3 - contd.

\begin{tabular}{|c|c|c|c|c|c|c|}
\hline 1 & 2 & 3 & 4 & 5 & 6 & 7 \\
\hline 5-methyl-2-furancarboxaldehyde & 955 & 109 & nd & nd & $0.201 \mathrm{a}$ & $0.708 \mathrm{~b}$ \\
\hline $\begin{array}{l}\text { 2,4-dihydroxy-2,5-dimethyl-3(2H)-furan- } \\
\text { 3-one }\end{array}$ & 977 & 101 & nd & nd & nd & 0.278 \\
\hline 2,5-dimethyl-4-hydroxy-3(2H)-furanone & 1046 & 128 & nd & nd & nd & 0.406 \\
\hline dihydro-4-hydroxy-2(3H)-furanone & 1153 & 74 & nd & nd & $1.233 \mathrm{a}$ & $2.541 \mathrm{a}$ \\
\hline $\begin{array}{l}\text { 2,3-dihydro-3,5-dihydroxy-6-methyl-4H- } \\
\text { pyran-4-one }\end{array}$ & 1151 & 144 & nd & nd & $0.289 \mathrm{a}$ & $1.841 \mathrm{~b}$ \\
\hline 3,5-dihydroxy-2-methyl-4H-pyran-4-one & 1187 & 142 & nd & nd & $0.055 \mathrm{a}$ & $1.399 \mathrm{~b}$ \\
\hline $\begin{array}{l}\text { 5-(hydroxymethyl)-2-furancarboxalde- } \\
\text { hyde }\end{array}$ & 1218 & 97 & nd & nd & $2.374 \mathrm{a}$ & $9.825 \mathrm{~b}$ \\
\hline sum of furans and furanones & & & nd & nd & $5.435 \mathrm{a}$ & $20.824 \mathrm{~b}$ \\
\hline \multicolumn{7}{|l|}{ Terpenes } \\
\hline Camphene & 952 & 93 & $1.233 \mathrm{a}$ & $1.504 \mathrm{a}$ & nd & nd \\
\hline$\alpha$-pinene & 980 & 93 & $0.908 \mathrm{~b}$ & $0.668 \mathrm{~b}$ & $0.182 \mathrm{a}$ & nd \\
\hline sum of terpenes & & & $2.141 \mathrm{~b}$ & $2.172 \mathrm{~b}$ & $0.182 \mathrm{a}$ & nd \\
\hline total amount of volatiles & & & $2.369 \mathrm{a}$ & $3.015 \mathrm{a}$ & $21.447 \mathrm{~b}$ & $46.175 \mathrm{c}$ \\
\hline
\end{tabular}

* - compounds identified on the basis of EI mass spectral data and reference standards.

** - retention indices on RTX-5 column.

$* * *$ - mass spectral ions used for semi-quantification.

nd - not detected.

$\mathrm{RC}$ - raw milk obtained from goats from the control group.

$\mathrm{RE}$ - raw milk obtained from goats from the experimental group with a higher content of unsaturated fatty acids.

$\mathrm{PC}$ - pasteurized milk $\left(85^{\circ} \mathrm{C} / 5 \mathrm{~min}\right)$ obtained from goats from the control group.

$\mathrm{PE}$ - pasteurized milk $\left(85^{\circ} \mathrm{C} / 5 \mathrm{~min}\right)$ obtained from goats from the experimental group with a higher content of unsaturated fatty acids.

$\mathrm{a}, \mathrm{b}, \mathrm{c}-$ small letters in rows represent the statistic differences relevant for $\alpha=0.05$.

Sulfur compounds were generally not identified in the raw milk, except for small amounts of dimethyl sulfone in the control milk. The greatest level of sulfur compounds was detected in the pasteurized milk from the experimental group. Although present in small amounts, sulfur compounds can lead to significant odor formation, as they have low OTs. Their concentrations in pasteurized samples (2.907 and $3.840 \mathrm{mg} \cdot \mathrm{kg}^{-1}$ ) significantly exceed their OT values for all compounds (from 0.0001 to $0.0003 \mathrm{mg} \cdot \mathrm{kg}^{-1}$ water) and may be related to the sensory differences between the raw and heat-treated milk samples, correlated with the cooked odor descriptor.

The DDGS-supplemented feed markedly increased the concentrations of a majority of methyl ketones, including 2-pentanone, 2-heptanone, 2-nonanone, and 2 -tridecanone. Pasteurization also leads to an increase in the concentration of two ketones, 2-pentanone and 2-undecanone.

As a result of heating, significantly higher levels of aldehydes were found in both the control (PC) and experimental samples (PE). The total concentration of aldehydes was highest in the pasteurized milk samples from the experimental group goats (PE). 
The results in Table 3 show that furaneol is present only in the heated experimental milk sample PE, at a concentration of $0.406 \mathrm{mg} \cdot \mathrm{kg}^{-1}$, which is more than 13 times its OT; this may be related to the processed odor descriptor that was strongly perceived by the sensory panel.

\section{Discussion}

The MUFA, MUFA cis, MUFA trans, PUFA, CLA, $n-3$, and $n-6$ fatty acid profiles shown in Table 1 agreed with those given in Cais-Sokolińska et al. (2015). Table 3 also presents the fatty acid methyl ester percentages for C:18, $n-6$, and $n-3$ acids and gives the AI and TI for the tested milk; these indices were lower than those found in the literature on goat's milk $(\mathrm{AI}=2.20-3.29$, Bouattour et al., 2008; Osmari et al., 2011). Silanikove et al. (2010) reported that several studies have shown that milk from grazing goats has better human nutrition quality parameters than the milk of goats fed indoors, with concentrations of CLA (C18:2c9t11 and C18:2t10c12) and polyunsaturated fatty acids being higher in the milk fat of pasture-fed goats, which also displayed significantly lower atherogenic indices.

Odor-generating milk compounds are the substrata of secondary catabolic transformations, transaminations, decarboxylation, desulphitation, and amino acid reactions with other compounds in the milk. During decarboxylation and transamination, reduced alcohol derivatives are produced, as are aldehydes and acids. All these compounds generate odors. The accumulation of such compounds in milk also has an effect on consumer acceptance. The amount and type of aroma compounds produced clearly confirms the sensory acceptability of the end product (Irigoyen et al., 2005).

The levels of particular compounds produced as a result of heating depends on the availability of their precursors, the temperature, and the heating period. Pasteurization, even low temperature pasteurization, causes changes in milk odor. Odor notes such as light sulfuric and green leaf begin to be detectable as a result of the increased concentration of sulfur compounds and aldehydes like hexanal (Karatapanis et al., 2006). Hexanal is formed in raw milk by lipid autoxidation of linoleic acid. Furthermore, heat can accelerate this reaction. Hexanal is thus often associated with the oxidative stability of lipids. In our research, levels of hexanal were highest in the PE samples, most probably due to increased levels of unsaturated fatty acids. These results show that this compound may be responsible for the processed odor note perceived by the sensory panel in the pasteurized milk samples. Furfural, on the other hand, is formed from 3-deoxysones in the course of Maillard reactions; this compound was found in pasteurized samples of both PC and PE milk at concentrations above its OT value $\left(3 \mathrm{mg} \cdot \mathrm{kg}^{-1}\right)$. The flavor of furfural has been described as sweet and almond-like, and may be associated with the dairy-sweet and overall dairy odor notes.

The higher concentrations of carboxylic acid found in the RE milk samples may be associated with the increased levels of polyunsaturated fatty acids caused by DDGS supplementation. A similar situation was observed in our previous study, 
where goats' diet was supplemented with Camelina sativa cake (Cais-Sokolińska et al., 2011).

There are many research studies showing that the application of heat during the pasteurization and UHT processes, as well as during high-pressure processing, affects the flavor profile of milk (Siefarth and Buettner, 2014; Contador et al., 2015; Smith et al., 2016). Such differences are seen in both sensory profile evaluation and levels of volatiles. In the present study, the odor descriptors of PC and PE milk shifted more towards cooked, dairy-sweet, overall dairy, and processed odor notes. Detailed HS-SPME-GC/TOFMS analysis of the volatiles showed that fatty acids increased from 0.112 to $8.654 \mathrm{mg} \cdot \mathrm{kg}^{-1}$ in the control samples and from 3.113 to $9.413 \mathrm{mg} \cdot \mathrm{kg}^{-1}$ in the experimental samples. This enhancement is a consequence of the degradation of milk triglycerides and is associated with the development of negative sensory attributes, such as rancid, sweaty, and burnt milk flavors (Pereda et al., 2008).

The presence of butyric acid in the milk investigated here may also reflect the enzymatic decomposition of fatty and amino acids. Butyric acid at lower concentrations (from 10 to $100 \mathrm{ppm}$ ) gives milk a slightly bitter flavor with a detectable sweet note. Larger amounts are typical of rancid products (Güzel-Seydim et al., 2000).

In our study, the DDGS-supplemented feed markedly increased the quantities of most methyl ketones. Methyl ketones are produced from short-chain fatty acids in the $\beta$-oxidation reaction caused by enzymes activated by molds (McSweeney and Sousa, 2000) and are associated with blue cheese aroma. However, they have rather high OT values $\left(1.38 ; 1.5\right.$, and $2.4 \mathrm{mg} \cdot \mathrm{kg}^{-1}$ for 2-pentanone, 2-heptanone, and 2-undecanone, respectively) (Preininger and Grosch, 1994; Kubickova and Grosch, 1998; Boonbumrung et al., 2001) and so are rarely mentioned as potent odorants in food products. According to Buttery et al. (1988), 2-nonanone has the lowest OT $\left(0.2 \mathrm{mg} \cdot \mathrm{kg}^{-1}\right)$; however, this is still higher than its concentration in all the milk samples examined here. In our present study, the total amount of all methyl ketones was below $0.6 \mathrm{mg} \cdot \mathrm{kg}^{-1}$; we therefore assume that they did not affect the flavor of the milk products investigated here.

Other compounds that may be formed during the heating of milk in the course of the Maillard reaction between lactose and amino groups include furans and furanones. A total of nine furans and furanones were identified. The most potent odorant, furaneol, has also been identified as a major potent odorant in sterilized goat's milk (Siefarth and Buettner, 2014). Similar results have been obtained by another research group that described an increase in furans and pyrans in breast milk that had undergone high-pressure processing (Contador et al., 2015).

\section{Conclusions}

Feeding goats with maize DDGS had a positive effect on the fatty acid profile of their raw milk. This was associated with an increase in the proportion of UFAs (especially PUFAs) and of CLAs (C18:2c9t11 and C18:2t10c12). The diverse composition of fatty acids present in the milk correlated with the olfactory perception and the profile of the volatile compounds within the milk. The volatile compound profile of the tested milk samples was generally differentiated by the levels of sulfur 
compounds, aldehydes (hexanal and furfural), and furanones (furaneol), since the concentrations of these compounds in the samples exceeded their OT values. In summary, pasteurized milk from DDGS-fed goats retains its characteristic animal odor, with a very intense cooked flavor. The result of the experiment indicates the need to conduct further studies on the effect of PUFA concentration on milk aroma profiles and on the volatile compounds that arise during pasteurization of milk. This will allow the development of a method of processing goat's milk rich in PUFAs.

\section{Competing interests}

The authors confirm that they have no conflicts of interest.

\section{References}

Anderson J.L., Schingoethe D.J., Kalscheur K.F., Hippen A.R. (2006). Evaluation of dried and wet distiller's grains included at two concentrations in the diets of lactating dairy cows. J. Dairy Sci., 89: 3133-3142.

B e n d a 11 J.G. (2001). Aroma compounds of fresh milk from New Zealand cows fed different diets. J. Agr. Food Chem., 49: 4825-4832.

Boonbumrung S., Tamura H., Mookdasanit J., Nakamoto H., Ishihara M., Yos hizawa T., Varany an ond W. (2001). Characteristic aroma components of the volatile oil of yellow Keaw mango fruits determined by limited odor unit method. Food Sci. Technol. Res.,7: 200-206.

B o u a t t o ur M.A., C a s a ls R., A 1 b a ne 11 E., S u ch X., C a j a G. (2008). Feeding soybean oil to dairy goats increases conjugated linoleic acid in milk. J. Dairy Sci., 91: 2399-2407.

B u t t e r y R.G., T u rn b a u g h J.G., L in g L.C. (1988). Contribution of volatiles to rice aroma. J. Agr. Food Chem., 36: 1006-1009.

Cais-Sokolińska D., Majcher M., Pikul J., Bielińska S., Czauderna M., Wójt o w s k i J. (2011). The effect of Camelina sativa cake diet supplementation on sensory and volatile profiles of ewe's milk. Afr. J. Biotechnol.,10: 7245-7252.

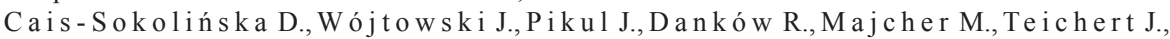
$\mathrm{B}$ a g n i c k a E. (2015). Formation of volatile compounds in kefir made of goat and sheep milk with high polyunsaturated fatty acids content. J. Dairy Sci., 98: 6692-6705.

Chilliard Y., Glasser F., Ferlay A., B ernard L., Rouel J., Doreau M. (2007). Diet, rumen biohydrogenation and nutritional quality of cow and goat milk fat. European J. Lipid Sci. Tech., 109: 828-855.

Cont a dor R., De lga do F.J., García-Parra J., Garrido M., R a mír ez R. (2015). Volatile profile of breast milk subjected to high-pressure processing or thermal treatment. Food Chem., 180: 17-24.

Coppa M., Martin B., Pradel P., L e otta B., Priolo A., Vasta V. (2011). Effect of a haybased diet or different upland grazing systems on milk volatile compounds. J. Agr. Food Chem., 59: 4947-4954.

Danków R., Ca is - S ok olińska D., Pikul J., Wó j tow ski J. (2003). Cytological quality of goat's milk (in Polish, with English summary). Med. Weter., 59: 77-80.

D e n n is T.S., Unruh-S n y d e r L.J., N e ary M.K., N e n n i c h T.D. (2012). Effects of co-grazing dairy heifers with goats on animal performance, dry matter yield, and pasture forage composition. J. Anim. Sci., 90: 4467-4477; doi: 10.2527/jas.2011-4643.

D r a k e M.A. (2004). Defining dairy flavor. J. Dairy Sci., 87: 777-784.

Gurung N.K., S o la i m a n S.G., R a n kin s D.L., M c El h e n n e y W.H. (2009). Effects of distillers dried grains with solubles on feed intake, growth performance, gain efficiency and carcass quality of growing Kiko $\times$ Spanish male goats. J. Anim. Vet. Adv., 8: 2087-2093. 
Gűze l-S e y d i m Z.B., S e y d i m A.C., Gren e e A.K., B o dine A.B. (2000). Determination of organic acids and volatile flavor substances in kefir during fermentation. J. Food Compos. Anal., 13: $35-43$.

Irig oy en A., Aran a I., C a s t i ell a M., Torre P., I b a nez F.C. (2005). Microbiological, physicochemical and sensory characteristics of kefir during storage. Food Chem., 90: 613-620.

I s 1 a m M.A., E k e berg D., Ruk ke E.O., Ve g a ru d G.E. (2015). Ex vivo digestion of omega-3 enriched buffalo skimmed milk. J. Funct. Foods., 19: 842-851.

K a r a g u l-Yuce e r Y., D rake M.A., C a dwa 11 a d e r K.R. (2001). Aroma-active components of nonfat dry milk. J. Agr. Food Chem., 49: 2948-2953.

Karatapan is A.E., B a deka A.V., Riganakos K.A., S avvaid is I.N., Kontomi $\mathrm{n}$ a s M.G. (2006). Changes in flavour volatiles of whole pasteurized milk as affected by packaging material and storage time. Int. Dairy J., 16: 750-761.

Kubickova J., Grosch W. (1998). Quantification of potent odorants in Camembert cheese and calculation of their odour activity values. Int. Dairy J., 8: 17-23.

L e o n a rd i C., B e r t i c s S., A r m e n t a n o L.E. (2005). Effect of increasing oil from distillers grains or corn oil on lactation performance. J. Dairy Sci.. 88: 2820-2827.

M c S w e e n e y P., S o u s a M. (2000). Biochemical pathways for the production of flavor compounds in cheeses during ripening: a review. Le Lait, 80: 293-324.

Mo i o L., Langlo is D., Etievant P., Addeo F. (1993). Powerful odorants in bovine, ovine, caprine and water buffalo milk determined by means of gas chromatography olfactometry. J. Dairy Res., 60: 215-222.

N u r s t e n H.E. (1997). The flavour of milk and dairy products: I. Milk of different kinds, milk powder, butter and cream. Int. J. Dairy Technol., 50: 48-56.

O s mari E.K., Cec a to U., M a cedo F.A.F., S o u za N.E. (2011). Nutritional quality indices of milk fat from goats on diets supplemented with different roughages. Small Ruminant Res., 98: 128-132.

Pereda J., Jaramillo D.P., Quevedo J.M., Ferragut V., Guamis B., Trujillo A.J. (2008). Characterization of volatile compounds in ultra-high-pressure homogenized milk. Int. Dairy J., 18: 826-834.

P ere ira R.A.G., O liveira C.J.B., Medeiros A.N., Costa R.G., Bomfim M.A.D., Queiroga R.C.R.E. (2010). Physicochemical and sensory characteristics of milk from goats supplemented with castor or licuri oil. J. Dairy Sci., 93: 456-462.

Preininger M., Gros ch W. (1994). Evaluation of key odorants of the neutral volatiles of Emmentaler cheese by the calculation of odour activity values. LWT - Food Sci. Technol., 27: $237-244$.

SAS, SAS/STAT Users Guide Release 6.12 (2006). SAS Institute, Cary, NC.

Serra M., Trujillo A.J., Guamis B., Ferragut V. (2009). Flavour profiles and survival of starter culture of yoghurt produced from high-pressure homogenized milk. Int. Dairy J., 19: $100-106$.

S i e farth C., B u ettner A. (2014). The aroma of goat milk: Seasonal effects and changes through heat treatment. J. Agr. Food Chem., 62: 11805-11817.

S i l a n i kove N., L e itner G., Merin U., Pros ser C.G. (2010). Recent advances in exploiting goat's milk: quality, safety and production aspects. Small Ruminant Res., 89: 110-124.

S mith S., S m ith T.J., D rake M.A. (2016). Flavor and flavor stability of cheese, rennet, and acid wheys. J. Dairy Sci., 99: 3434-3444.

S p it ze r J., B u e t t n e r A. (2010). Characterization of aroma changes in human milk during storage at $-19^{\circ} \mathrm{C}$. Food Chem., 120: 240-246.

S t a m p a n o i C.R. (1994). The use of standardized flavor languages and quantitative flavor profiling technique for flavored dairy products. J. Sens. Stud., 9: 383-400.

S te in shamn H., Ingling st a d R.A., Ekeberg D., Mølmann J., Jørgen s en M. (2014). Effect of forage type and season on Norwegian dairy goatmilk production and quality. Small Ruminant Res., 122: 18-30.

U 1 b r i c h t T.L.V., S o u th g a t e D.A.T. (1991). Coronary heart disease: seven dietary factors. Lancet, 338: 985-992.

Wój tow ski J., Ślós a r z P., Ma lecha W., Danków R. (2002). Ultrasound measurements of 
goat's mammary gland cisterns during lactation (in Polish, with English summary). Med. Weter., 58: 977-980.

Wó j tow ski J., Danków R., Skrzy pek R., F ahr R.D. (2003). The fatty acid profile in kefirs from sheep, goat and cow milk. Milchwissenschaft, 58: 633-636.

Received: 19 X 2018

Accepted: 17 I 2019 